\title{
THE UNITED KINGDOM
}

\author{
Above all, [tax treaties] impose acceptable standards . . . where such \\ standards would otherwise be absent.
}

—Deputy chairman of the Board of Inland Revenue

The United Kingdom has the widest tax treaty network of any country in the world. It played a very involved role in the development of the League of Nations and OECD model conventions, and the UK-US treaty of 1945 is regarded as having set the precedent for modern tax treaties. ${ }^{1}$ This chapter focuses on the 1970s, a period when the tax treaty network expanded rapidly into recently independent lower-income countries that were certainly keen to attract inward investment. Britain entered into negotiations with about forty lower-income countries during the period 1970-79, successfully concluding agreements with just over half. Most of these agreements are still in force today.

A conventional tax competition logic would suggest that the UK concluded a large number of tax treaties with lower-income countries because they were competing for British investment. In keeping with the arguments of previous chapters, this chapter develops that tax competition logic in two directions. First, it demonstrates that the main driver of the UK's treaty negotiations with lowerincome countries was competition between the UK and other home countries of multinational investors for outward investment opportunities. Second, it shows that two different logics of competition existed: one within the tax expert community, and another among nonspecialist stakeholders. For the tax specialists, including treaty negotiators in the Board of Inland Revenue, the goal of tax treaties was to export "acceptable" OECD tax standards wherever British firms operated. Nonspecialist stakeholders were motivated by a combination of the tax treaty myth and the perceived effects of tax treaties on the short-term effective tax rate of UK multinationals. This led to clashes of preferences, which the Inland Revenue 
generally dismissed as misunderstandings or parochialism. The role played by expert technical knowledge in shaping the preferences of tax specialists is illustrated by the private sector actors, who did not align with each other but with the two civil service camps, based on their level of expertise.

Evidence presented in this chapter is drawn from civil service documentation released under the United Kingdom's thirty-year rule. It covers the decade from 1970, the most recent full decade for which these records were available, and one in which many treaties still in force today were negotiated with lower-income countries in Africa and Asia. The documents reviewed include internal civil service correspondence, minutes of negotiation meetings, and correspondence between the UK and other countries' negotiating teams. The focus is therefore on the variables driving the UK's actions, rather than those internal to the lowerincome country. We cannot tell conclusively from this evidence what motivated the lower-income country, but by mapping the process of each negotiation, it is possible to determine the extent to which the lower-income country was driving forward negotiations, or acquiescing to the UK's enthusiasm. Where the latter is the case, this illustrates how competition among capital-exporting countries is responsible for the emergence of new tax treaties, rather than purely among capital-importing countries as much of the literature assumes.

The rest of the chapter proceeds as follows. The next section briefly discusses the archival documents used. The chapter then establishes some general findings about roles and attitudes of different stakeholder groups in the treaty-making process, drawing from some specific examples as well as overriding policy considerations. I then move on to consider three cases in particular: the UK's negotiations with Egypt, Nigeria, and Brazil. Egypt shows the conclusion of a new agreement, Nigeria the renegotiation of a colonial agreement, and Brazil an unsuccessful negotiation in spite of strong demand from British businesses. In each of these cases, we see evidence that lobbying by tax specialists from British firms was crucial to determining the UK's position, as well as evidence of conflicting preferences between treaty negotiators and nonspecialist stakeholders.

\section{Context}

The evidence used in this chapter is from the UK National Archives, which releases civil service files thirty years after they have been closed (seventy years for files that include information on identified people's tax affairs). Each file is recorded in an online database that includes its name and a short description. To find the relevant files, I searched this database for the terms "double tax," "double taxation," and "tax treaty," which yielded 2,301 results when I first conducted the 
search in 2014. The majority of these were country-specific files originated from the Inland Revenue or the FCO and its predecessors. They include internal civil service correspondence, correspondence between countries, and minutes of negotiation meetings. This means that they include both the internal thinking of the UK and the positioning of the negotiating partner, supplemented on occasion by intelligence about its motivations from other British sources.

Most of the country files indicate that sporadic contact between the two sides was the norm before any serious negotiations were initiated. The UK may have made tentative inquiries, as in the case of Latin American countries, or an ambassador from a lower-income country may have expressed an interest that the UK judged not to reflect a serious intent on behalf of that country's tax treaty decision makers. The UK entered into serious discussions with around forty lower-income countries during the 1970s, shown in table 5.1. The median length of time from the UK's first successful contact with a country with a view to negotiating a tax treaty to signature was just over three years, but a significant number of negotiations took over six years. The median time from first contact to ratification by both parties was as much as five years.

Negotiations were undertaken by a small team of officials within the Board of Inland Revenue. Most of the information used in this chapter is drawn from that team's files, although most treaties also have a corresponding Foreign Office file, which may include communication between the embassy and the desk officer in London, but is often purely procedural. In general, for each treaty the file begins with correspondence with the report of a conversation with a lower-income country, or correspondence either between the Inland Revenue and its counterpart or between the Inland Revenue and the British embassy. Preliminary discussions then give way to a formal request to start negotiations, and the Inland Revenue circulates a written request for comment to the Treasury, FCO, and the Department (or Departments, depending on the date) of Trade and Industry (DTI).

A typical negotiation consisted of an exchange of drafts (or simply the UK sending its draft and the lower-income country responding with comments), then a first round of negotiations in person. Finding a mutually convenient time to meet was a lengthy process when correspondence was principally by air mail, and a year's delay at this point for purely practical reasons was not atypical. After the first round of negotiations, the file usually includes formal minutes and a more informal memo circulated to accompany them, giving the negotiators' impressions of their opposite numbers. Further correspondence on outstanding issues usually led to a second round of negotiations, at which the agreement was initialed, signaling acceptance at an official level. The treaty was then subject to final checks, including translation and finalizing the definition of countries with the FCO, before it was signed. Sometimes errors, legislative changes, or a change of heart by one side could lead to 
TABLE 5.1. UK negotiations with lower-income countries, 1970-79

\begin{tabular}{|c|c|c|c|c|c|}
\hline & $\begin{array}{l}\text { INITIATOR OF } \\
\text { NEGOTIATIONS }\end{array}$ & $\begin{array}{l}\text { DISCUSSIONS } \\
\text { OPENED }\end{array}$ & $\begin{array}{l}\text { FIRST ROUND OF } \\
\text { NEGOTIATIONS }\end{array}$ & $\begin{array}{l}\text { TREATY } \\
\text { SIGNED }\end{array}$ & $\begin{array}{l}\text { TREATY IN } \\
\text { FORCE }\end{array}$ \\
\hline Argentina & UK & 1979 & 1980 & & \\
\hline Bangladesh & UK & 1976 & 1977 & 1979 & 1980 \\
\hline Botswana & [Renegotiation] & 1974 & 1974 & 1977 & 1978 \\
\hline Brazil & UK & 1972 & 1973 & & \\
\hline Colombia & UK & \multicolumn{2}{|c|}{ Informal discussions only } & & \\
\hline Czechoslovakia & UK & 1975 & 1977 & 1990 & 1991 \\
\hline Egypt & UK & 1976 & 1976 & 1977 & 1980 \\
\hline Fiji & - & 1973 & 1974 & 1975 & 1976 \\
\hline Gambia & - & 1974 & 1974 & 1980 & 1982 \\
\hline Ghana & [Renegotiation] & 1974 & 1974 & 1977 & 1978 \\
\hline Greece & UK & \multicolumn{2}{|c|}{ Informal discussions only } & & \\
\hline Hungary & UK & 1976 & 1977 & 1977 & 1978 \\
\hline India & UK & 1976 & 1976 & 1981 & 1981 \\
\hline Indonesia & - & & & 1974 & 1976 \\
\hline Iran & UK & 1973 & 1975 & & \\
\hline Ivory Coast & - & 1978 & 1979 & 1985 & 1987 \\
\hline Jamaica & [Renegotiation] & 1969 & 1969 & 1973 & 1973 \\
\hline Kenya* & [Renegotiation] & 1971 & 1971 & 1973 & 1977 \\
\hline Korea & - & 1974 & 1975 & 1977 & 1978 \\
\hline Lesotho & - & \multicolumn{2}{|c|}{ Informal discussions only } & & \\
\hline Malaysia & [Renegotiation] & 1971 & 1975 & & \\
\hline Mauritius & - & 1974 & 1975 & 1981 & 1981 \\
\hline Mexico & UK & 1978 & & & \\
\hline Morocco & Counterpart & 1970 & 1976 & 1981 & 1990 \\
\hline Nigeria & UK & 1978 & 1979 & 1976 & 1978 \\
\hline Philippines & Counterpart & 1974 & 1975 & 1976 & 1978 \\
\hline Poland & UK & 1975 & 1975 & 1975 & 1978 \\
\hline Romania & Counterpart & 1975 & 1975 & 1975 & 1977 \\
\hline Saudi Arabia & UK & 1977 & & & \\
\hline Spain & UK & 1973 & 1975 & 1975 & 1976 \\
\hline Sri Lanka & Counterpart & 1972 & 1974 & 1979 & 1980 \\
\hline Sudan & [Renegotiation] & 1973 & 1974 & 1975 & 1977 \\
\hline Swaziland & - & \multicolumn{2}{|c|}{ Informal discussions only } & & \\
\hline Tanzania* & Counterpart & 1976 & 1977 & & \\
\hline Thailand & UK & 1974 & 1976 & 1981 & 1981 \\
\hline Tunisia & Counterpart & 1975 & 1976 & 1982 & 1984 \\
\hline Turkey & UK & 1978 & & & \\
\hline Uganda* & - & 1971 & & & \\
\hline Yugoslavia & - & 1975 & 1976 & 1981 & 1982 \\
\hline
\end{tabular}

Source: National Archives, various files. Where no information was available in the archives, this is indicated by a dash. Blank spaces indicate that this stage of negotiation did not take place.

*Kenya's, Tanzania's, and Uganda's negotiations with the UK began as part of a joint negotiation on behalf of the East African Community. 
amendments being made at this stage, either to the text itself or via a protocol, signed at the same time. Ratification followed, which in the UK involved the minister of state presenting the agreement to a parliamentary committee: the file usually includes a copy of the briefing given to the minister, explaining any salient or unusual features of the treaty, and giving suggested answers to anticipated questions; while these briefings are usually formulaic, they sometimes include information explaining the UK's reasoning. It was not unusual for signature or ratification to be delayed in the lower-income country, and the files sometimes show the UK negotiators seeking to expedite ratification by the other side.

There are also some files relating to the UK's general negotiating position, such as correspondence within and between departments relating to a crossdepartmental review of DTTs. Another set of files records meetings and correspondence with business organizations, including quarterly "state of play" reports on all the UK's negotiations, which were compiled as briefing documents for civil servants attending these meetings. These are discussed in more detail in the sections that follow.

\section{The UK's Active Pursuit of Tax Treaties}

Since the earliest files discussing potential treaties, correspondence inside the UK civil service indicates that the UK was not merely a passive respondent to requests from lower-income countries, "stand[ing] ready with model treaties in hand," but rather it was actively shaping its own treaty network. ${ }^{2}$ Already in 1957, discussion of a potential agreement with Colombia states, "For years we have been unsuccessfully trying to conclude an agreement with a South American country without any success. . . . This is, therefore, the only area of the world, apart from the countries behind the Iron Curtain in which we have made no progress." 3

With Turkey, the UK proposed talks in 1978 and again in 1979, but a note in 1981 indicates that the Turks "have expressed no enthusiasm" for a treaty. ${ }^{4}$ Similarly, the UK sent a draft treaty to Czechoslovakia in 1975, but in 1976 a civil servant wrote that "despite reminders, the Czechs have not responded." In the latter case, negotiations did take place in 1977 and 1978 but ended in a stalemate because "the Czechs [were] refusing to reduce their tax on royalties."6 Iran's previous "apparent lack of response" to the UK gave way to a "willing[ness] to have talks" in 1974, but later the same year the civil service files record that "our embassy is pressing the Iranians as much as we can."7 Another example is Mexico, with which the UK requested negotiations in 1978 after an approach to the Inland Revenue from business groups. ${ }^{8}$ The next mention in the "state of play" reports is in 1981, which record that the UK had been "told they are not yet ready." 
While business lobbying often underpinned the decision to pursue a treaty with another country, the Inland Revenue frequently made a first approach once it saw that a country had begun to negotiate with competitor states. In 1961, for example, the UK sent a draft treaty to Thailand after the latter began to negotiate tax treaties with other countries, even though there was no interest from British businesses. ${ }^{10}$ In the early 1970s, it tried again, noting a handful of requests from businesses as well as that Thailand had by that point concluded tax treaties with many competitor countries. After a meeting in 1972 with "the only one who is able to talk about Double Taxation Agreements" in Thailand's revenue department, a British Foreign Office official concluded that, "in principle they would be interested but it was not likely that Thailand would take the initiative." 11 A memo from October 1973 notes that "Thailand does not seem to be very interested in a DTA with the United Kingdom."12

Similarly, when the UK approached Bangladesh about a treaty in 1976, a background note in the file states that "there is not much pressure in the United Kingdom for a treaty with Bangladesh,"13 and that the UK's initiation of the treaty was "partly because other countries had opened negotiations with Bangladesh."14 Bangladesh's revenue officials were apparently not interested at first, and the UK "made the running," including by applying diplomatic pressure. ${ }^{15}$ By the second round of negotiations in Dhaka, the head of state, Ziaur Rahman, was being given daily updates on progress. ${ }^{16}$ Nonetheless, the reluctance of Bangladesh's negotiators to surrender their taxing rights is visible in the meeting minutes. A Bangladeshi negotiator argued that the UK should break precedent and allow Bangladesh to retain higher withholding tax rates because it was "practically the poorest of the world's underdeveloped countries," to which his UK counterpart responded that "the United Kingdom did not regard a double taxation convention as a vehicle for giving financial aid, no matter how deserving the partner country." 17

If the UK was keen to sign treaties with all lower-income countries, but many of them rejected its overtures, this would be consistent with the view that it is policy in the lower-income country that is the primary determinant of the timing of treaty negotiations. The picture painted by the files, however, goes beyond that. The UK actively reached out to certain lower-income countries to urge them to open negotiations, exerting diplomatic pressure where necessary. For many, the decision to respond positively to British overtures was characterized more by acquiescence than by enthusiasm. Excluding renegotiations, three-quarters (seventeen of twenty-three) of the negotiations listed in table 5.1 for which information is available were initiated by the UK. Where lower-income countries made the first move, this was often because they wanted to renegotiate the terms of an existing agreement put in place when that country was a British colony. 


\section{Actors and Actions in UK Treaty Making}

In this section, I outline the roles of different groups of stakeholders in the decisionmaking processes surrounding the UK's tax treaties. Specifically, I examine the preferences of tax treaty specialists in the Inland Revenue, who led negotiations, and those of nonspecialists, in particular those in the rest of government. I also consider what happened when these different preferences created conflict between the two groups.

\section{Tax Experts: Dissemination of Technical Standards}

For specialists inside the Inland Revenue, the major causal effect of tax treaties was not, despite their formal title of "for the avoidance of double taxation and the prevention of fiscal evasion," the elimination of double taxation (fiscal evasion rarely seems to get a mention either). The reason for this was that the UK, like many other countries, had taken unilateral steps to prevent double taxation of its firms operating overseas by giving them a credit against their UK tax bill for any taxes paid overseas.

Recognition of this dates back to at least 1957, when an Inland Revenue civil servant wrote that, with regard to one treaty, "the United Kingdom taxpayer gets very little benefit out of it: he will get credit for the tax paid in Colombia against the tax due on the same income in this country whether we have an agreement or not."18 Two decades later, in 1976, a cross-department review of the UK's approach to international double taxation, led by the Inland Revenue, made the case even more boldly: "In the absence of an agreement there is no question of United Kingdom investors being doubly taxed." 19

What, then, was the purpose of a tax treaty for the Inland Revenue? That same note from 1957 records that, for a board of directors in the UK, "the advantages of a double taxation [agreement] need no stressing." ${ }^{20}$ It goes on to argue that a tax treaty "at once assures the directors that they will be taxed according to internationally accepted rules and they will not be subject to discrimination." 21 These are often referred to as "intangible benefits," and they are mentioned by government officials throughout the period under consideration. According to the 1976 review, "These include protection against fiscal discrimination, the establishment of a framework within which the two tax administrations can operate, and the expectation that an overseas authority which has negotiated a treaty will at least try to apply it reasonably." The deputy chairman of the Board of Inland Revenue in 1976 was Alan Lord, who twenty years earlier had represented the UK on the new OEEC committee that would eventually become the OECD's CFA. According to him: "Above all, treaties impose acceptable standards for allocating 
profits to branches and subsidiaries and for dealing with transfer pricing in countries (some of them within the EEC [European Economic Community]) where such standards would otherwise be absent."22

For the specialists, tax treaties were therefore tools through which the UK, which had always taken a prominent role in the development of the international tax system, ensured other countries' participation in it. This would be especially beneficial for British businesses in the case of lower-income countries, including those newly independent, where, as one official wrote, "protection against fiscal discrimination is generally worth more ... because they are more likely to include deliberately discriminatory fiscal practices in their general law than are developed countries."23 A memo from as early as 1949 expresses the view that "the United Kingdom particularly has much to gain from the increasing adoption, particularly by under-developed countries, of sound principles of income taxation and from the conclusion on sound lines of conventions for the relief of double taxation."24 Treaties were largely understood as means to ensure that British firms could be competitive when they decided to invest, rather than to make investment in the treaty partner more attractive in the first place. Thus, treaties would increase investment from the UK to the treaty partner, but not by influencing business decisions; rather, they gave British investors a helping hand.

The effect of treaties on outward investment from the UK was not a trivial matter during the 1970s but an important policy question. Treasury policy was to limit the impact of outward FDI on the balance of payments by encouraging it to be done out of retained earnings, investment currency, or foreign currency borrowing. In 1973, at a meeting of the cross-Whitehall Tax Reform Committee handling changes to corporation tax, a Treasury official argued against measures that would prioritize overseas investment, because of the effect on the balance of payments. The concern was about foreign exchange reserves, which could be protected more through income from exports than from direct investment; furthermore, the likely shift in manufacturing abroad as a result of outward investment would increase imports. ${ }^{25}$ Discussing this point, the 1976 review concluded that the treaty network at that point "neither encourages nor discourages overseas investment in fiscal terms compared with domestic investment, except where matching credit [i.e., tax sparing clauses] is provided." ${ }^{26}$ Around this time, the Inland Revenue was arguing against conceding Brazil's demands for more comprehensive concessions in a tax treaty on the grounds that they "would mean that we were according outward investment a higher priority than hitherto with all that that implied for the balance of payments and the domestic economy."27

The community of tax specialists who shared this analysis and these objectives was not limited to the Revenue itself: it extended into the private sector. In December 1971, Alan Davies of Rio Tinto Zinc (RTZ), chair of the tax committee 
of the Confederation of British Industry (CBI), wrote to Alan Lord. The letter outlined the limitations of the Revenue's current approach to consultation, which was to solicit comments from industry by letter once negotiations were initiated. Davies cited "a peeved feeling on our side that some more confidence would be justified," and argued for more informal discussion about the progress of negotiations. ${ }^{28}$ The informal tone of Davies's letter perhaps reflects a personal familiarity with the Inland Revenue officials concerned. For example, he attended meetings of the United Nations Ad Hoc Group of Experts on Tax Treaties between Developed and Developing Countries, representing the ICC, as did Inland Revenue negotiators. ${ }^{29}$

The result was a system of regular quarterly meetings between tax specialists from industry groups (the CBI, British Insurance Association, and Chamber of British Shipping) at which detailed information on the "state of play" in negotiations was divulged, and comments sought on specific topics. ${ }^{30}$ The first such meeting took place in March 1972, and they continued for at least the next decade. At each meeting, the Inland Revenue participants were supplied with a status report on current and planned negotiations, which they shared verbally with the business representatives on the condition that the information was not shared outside of the small, expert group. When negotiations reached a difficult point, the matters of contention would often be discussed in this forum. The question of withholding tax clauses in the treaty with Kenya, discussed in the prologue to this book, came up at the very first meeting. The discussions are summarized in the minutes with a statement that "an agreement on some basis preferably with as low a rate as possible was preferable to no agreement at all." ${ }^{\prime 1}$

Before finalizing a treaty with Thailand, the Inland Revenue consulted with its tax contacts in the shipping industry, who were concerned about the precedent the agreement would set. A subsequent briefing note for the second round of negotiations stated that "the question is one of principle, and as the amount of money involved is small, we have decided, after consultation with the General Council of British Shipping, to have no Shipping Article in the Convention to avoid providing a precedent with other, and more important, countries." 32

In contrast, a parallel negotiation with Tanzania broke down over the shipping question after discussions among the same group of experts. ${ }^{33}$ The context to this firm line was the creation of a precedent ahead of anticipated negotiations with India, where the sums at stake were much larger.

Thus, British negotiators saw tax treaties primarily as instruments that ensured British overseas investment would be taxed in a manner consistent with the standards set out in the OECD model convention, which they had helped draft. When negotiating with lower-income countries, they commonly encountered situations in which their opposite numbers wanted a greater share of the tax base 
than the OECD model treaty permitted them, and where the successful conclusion of a tax treaty might depend on some deviation from the OECD approach. Decisions about how to respond to such dilemmas were made by Inland Revenue civil servants in consultation with their fellow tax experts from the business world.

\section{Other Actors: Competition for Outward Investment Opportunities}

Here I consider the preferences of nonspecialists, for whom tax treaties were also tools to increase the competitiveness of British firms abroad. A lack of detailed taxation knowledge, frequently lamented both by them and by the specialists, left them to rely on their own ideas, which were not necessarily grounded in facts. This would lead to conflicts, during which the Revenue would sometimes try to convince them that their faith in the effect of tax treaties was misplaced. "There can be little doubt that tax treaties are a means of stimulating trade and investment between the treaty partner countries," wrote the private secretary to the Treasury minister responsible for tax policy in 1976. "On the other hand their importance is sometimes exaggerated." 34 The UK's lead negotiator noted in 1974, referring to Brazil, that "we should not over emphasise the importance of a DTA. It generally only affects income flowing from one country to another whereas in the short term a company will not remit much in the way of profits and will not be too bothered in the absence of an agreement." 35

Most civil service nonspecialists who engaged with tax treaty matters during the 1970s wanted British firms that were eligible for investment-promoting tax relief in lower-income countries to receive a corresponding credit (often referred to as tax-sparing credit) against UK tax, to ensure that they could retain the benefit of the tax relief when they repatriated their profits. As the 1976 review notes, in outlining the priorities of different departments, "the main cash benefit for the investor [from a tax treaty] is matching credit for pioneer reliefs." ${ }^{36}$ The difficulty was that this was not the Inland Revenue's priority from tax treaties, and at times (as in the case of Brazil, below) the two priorities even came into conflict.

A good example can be seen in the negotiations with Zambia, one of the few cases in which negotiations were initiated by the lower-income country. When the Revenue consulted businesses ahead of these negotiations, tax-sparing provisions emerged as a priority for UK firms. ${ }^{37}$ British negotiators did not disclose this to Zambia, which had already indicated an interest in a tax-sparing clause when requesting negotiations. ${ }^{38}$ Instead, they tried to use Zambia's desire for a tax-sparing clause as a bargaining chip, offering it if Zambia would accept an agreement that prevented it from charging any withholding tax on royalty payments. ${ }^{39}$ Zambia chose instead to keep its 10 percent withholding tax and forgo the tax-sparing 
clause, and so the British negotiators had to write to their Zambian counterparts soon after the conclusion of negotiations to unilaterally offer the tax-sparing credit that they had previously withheld, claiming that they had subsequently been pushed by another country to offer similar terms. ${ }^{40}$

The Inland Revenue sought to keep input from other departments limited and compartmentalized, and did not welcome their attempts to influence its priorities. The Treasury, DTI, and Foreign Office would each be consulted on treaties once negotiations were opened, and on specific questions concerning their content, but the Revenue would often reject their requests to be able to influence its priorities.

During late 1972 and 1973, an extraordinary correspondence opened up between the FCO and Board of Trade, on the one hand, and the Inland Revenue, on the other. The former were frustrated by their inability to influence the latter's negotiating priorities. At a cross-Whitehall meeting in April 1972, the Revenue had merely invited them to submit "shopping lists" for treaties they would like it to negotiate. ${ }^{41}$ "We have already forfeited opportunities for investment in Brazil, notably to the Germans and Japan and, as a matter of commercial policy, it is important that we should not place our traders at a disadvantage when seeking out investment opportunities in the future," argued one official from the Board of Trade in February 1973. "As you know, we have been concerned that the corporation tax system should not so limit the scope for tax sparing as to damage the UK's ability to export to and invest in lower-income (and highly competitive) overseas markets. For this reason, we place great importance on the conclusion, as quickly as possible, of double tax agreements with our developing trading partners which allow for tax sparing." ${ }^{\prime 2}$

The Revenue rebuffed this pressure, even refusing to share a list of current negotiating priorities or negotiations that were under way, because "a high degree of confidentiality attaches to our negotiations with particular countries." ${ }^{\prime 3}$ The reference to confidentiality is ironic, because this correspondence took place at the same time as the Revenue had begun quarterly meetings with tax specialists from businesses, at which exactly this information was disclosed.

"I find the Inland Revenue's attitude and behaviour quite extraordinary," wrote an official in the FCO's financial relations department, as part of correspondence that passed between these other departments. "I cannot imagine that any other department in Whitehall would behave in this way. Nor would we have allowed any other Department to get away with behaviour like this for quite so long. I am quite clear we must call a halt now." 44 Another lamented "a dispiriting and unfruitful confrontation with the Inland Revenue." ${ }^{45}$ The problem for the FCO, in particular, was that it lacked a coherent position within itself, and the technical 
expertise to develop one. "The subject is difficult and mastering it is undoubtedly time-consuming" mused one FCO official. ${ }^{46}$

It was not only officials from other departments who had trouble influencing Inland Revenue officials: their own ministers faced the same problem. In general, politicians had little involvement in tax treaties at all. At the start of the 1970s, negotiators worked within enabling powers set by Parliament and would seek ministerial guidance only when making a concession that had not previously been given in negotiations. There seems to have been no political involvement in the decision with whom to negotiate, and the minister in charge, the financial secretary to the Treasury, usually did not see a treaty until bringing it before Parliament for ratification.

The technical complexity of tax treaties was inevitably a barrier to effective political scrutiny, but this must surely have been combined with the short tenure of financial secretaries: eleven people occupied the position during the 1960s and 1970s, with an average tenure of two years. ${ }^{47}$ As a civil service memo from 1975 notes: "It is however a long time since the agreements took their present form and the Treasury Ministers of today have had no experience in this field outside government." 48

The longest-serving financial secretary, Robert Sheldon, in post from February 1975 to April 1979, was also the only one for whom the Treasury archives record any attempt to scrutinize the activities of his civil servants on their treatymaking activities. In December 1975, Sheldon was being briefed ahead of a parliamentary debate at which he was to propose the ratification of several tax treaties. He expressed concern that he was expected to propose an agreement in Parliament that he had not seen beforehand. He suggested that parliamentary approval be dropped and replaced with greater ministerial oversight. ${ }^{49}$ At a subsequent meeting in May 1976, Sheldon wanted "to reassure himself in the absence of quantifiable data that when he is asked to recommend a double taxation agreement to the House as a reasonably balanced deal he can happily do this." ${ }^{\prime 5}$

During the December 1975 debate, Sheldon undertook to look into the costs and benefits of tax treaties. This commitment provoked lengthy exchanges within the civil service, both to examine costing methodologies and to explain what officials saw as the problem with this approach. "What might be a reasonably balanced agreement as a whole," Sheldon's private secretary wrote to him, "might appear otherwise if the disadvantages were more easily quantifiable than the advantages." Furthermore, such costing information might undermine negotiations. Demonstrating that the UK had obtained a good deal might provoke the other country to seek to change it, while a bad deal would set a precedent. ${ }^{51}$

These notes indicate the difficulty faced by a minister trying to exert some influence over a policy area with which he was unfamiliar. During the mid-1970s, 
the UK had been seeking to amend the articles of its tax treaties covering the taxation of dividends, to reflect changes to its corporation tax system. The civil servant who first briefed Sheldon commented, "I got the impression that he does not realise-or did not until I pointed it out to him-that double taxation agreements also deal with other matters than dividends. ... He seemed surprised when I told him we had sixty plus agreements in operation." 52

This lack of understanding is also apparent in the minutes of the May 1976 meeting. Sheldon questioned "what the OECD Model was and what we would do if it turned out not to provide an advantageous pattern for the UK." ${ }^{33}$ This question illustrates a lack of basic familiarity with the area, and is all the more surprising because Sheldon's brief would also have included ministerial responsibility for the UK's input into the OECD model. To make matters worse, Sheldon cut the meeting short before officials could give a full explanation.

A third category of nonspecialist stakeholder was those within business, who were evidently very keen to influence UK policy. At the nonspecialist level, businesses were able to influence the positions of other parts of government, including the FCO and DTI, but this rarely translated into treaties. Geographic departments in the FCO, in particular, were often persuaded by businesses, which lobbied British embassies, to advocate new British tax treaties. For example, "UK finance houses and business interests are adamant that we are losing a significant amount of business in Spain because there is no double taxation agreement," wrote an official in the FCO's southern Europe department. ${ }^{54}$ These positions fed into the central FCO departments, in particular the economists' department and financial relations department, which as we have seen were furious that the Inland Revenue would not heed their concerns about the competitiveness of British businesses. Meanwhile, the Inland Revenue seemed content to divide and rule the geographical departments.

Business lobbying via these departments met with limited success, partly because those other parts of government had limited influence on the Revenue but also because one part of the private sector undermined the other, a fault line that sometimes ran within, rather than between, businesses. As the Brazil case study, below, will illustrate, private sector tax specialists sometimes directly contradicted their nonspecialist colleagues when in discussion with the Inland Revenue. While some of these specialists evidently felt it necessary to sacrifice the intellectual purity and consensus of the epistemic project for the sectional interests of their own firm, in many cases the business-Revenue consultations were more a strategic discussion of how to manage their respective nonspecialist constituencies. ${ }^{55}$

A memo from the CBI to the DTI, covering a wide range of policy and not written by tax specialists, states that tax treaty "negotiations should not be left exclusively to the Inland Revenue (whose main concern is naturally the minimi- 
sation of losses to the Exchequer). ${ }^{\prime 56}$ A year later, an Inland Revenue official was "subjected to a two-hour intense grilling" by CBI representatives who were not tax specialists at a cross-Whitehall consultative meeting. They had apparently "suggested that future negotiations for double taxation agreements would better be dealt with by a department other than the Inland Revenue since the negotiations were currently carried out for the United Kingdom by narrow specialists who were so blinkered by the technicalities of taxation that they failed to see the full view of the picture." ${ }^{\prime 7}$ The CBI delegation also expressed the view that the Inland Revenue's consultation with tax experts from industry "was not really satisfactory since it was restricted to 'taxmen." 58

The "taxmen" from industry felt obliged to apologize for their colleagues' actions in subsequent discussions with the Inland Revenue. ${ }^{59}$ Later that year, a covering note from the chair of the CBI's tax committee to the Inland Revenue accompanying a copy of the CBI's submission to the UK-Egypt joint economic commission made another apology for the author's nonspecialist colleagues. "We were intending to discuss this question with you before we let the Department of Trade have any comments," it said, but short notice had prevented it. "Our overseas Department receives such requests from the Department of Trade from time to time and we are now trying to ensure that any answer is given by the tax experts who attend the joint CBI/ICC Working Group meetings at Somerset House [the Inland Revenue office] rather than by those who are not too familiar with the technical implications. This should avoid any future complications over such representations." ${ }^{30}$

We can see, therefore, that nonspecialist actors had different priorities than those of the Inland Revenue and the tax committees from business with which the Revenue consulted. Civil servants outside the Inland Revenue, as well as the business lobbyists with whom they interacted, were frustrated by their inability to influence the Inland Revenue.

\section{Sample Negotiations}

The previous section demonstrated two different motivations among different stakeholders for the UK pursuit of tax treaties. The tax treaty specialists sought to surround British businesses with the protective shield of OECD standards, while others focused on the specific tax advantages that British businesses would gain and the competitive edge this might give them. Tax competition driven by nonspecialists faced a potential "firewall" if it met opposition from specialists. ${ }^{61}$ In this section I extend the analysis with greater specificity, by focusing on individual treaty negotiations. Egypt is an example of a successful negotiation, Nigeria of a renegotiation, 
and Brazil of an unsuccessful stalemate. In all three cases, we see evidence that the preferences of British businesses were the primary motivating factor behind individual negotiations. We also see, however, that these priorities had to coincide with the range of options deemed acceptable by Inland Revenue negotiators. In both the Nigerian and Brazilian examples, the lower-income country sought to negotiate on its own terms, not those dictated by the OECD model. While British businesses were desperate, the Inland Revenue held firm to its view of the "acceptable standards" a treaty should contain, and the only difference in outcomes between the two cases was that Nigeria backed down while Brazil held firm.

\section{Egypt}

The UK's 1976 treaty with Egypt is a typical example among those examined for this chapter. It resulted from pressure exerted on the UK government by British businesses operating in Egypt. Influential businesses sought a treaty either to limit Egypt's ability to tax their operations in accordance with rules set out in the OECD model or to pursue a tax-sparing clause. They explicitly pointed to the competitive disadvantage they faced in Egypt in the absence of a functioning treaty. Negotiations took some time to get off the ground, because Egyptian revenue officials were concerned about the revenue losses; yet when negotiations took place, Egypt did not have the technical capacity to defend its tax base. British officials, meanwhile, did not engage enthusiastically until the CBI informed them that British businesses were keen to see an agreement.

Egypt and the UK exchanged correspondence about tax treaties sporadically during the 1950s and 1960s, without ever concluding an agreement. Each side took the initiative at different times, while changes in civil service staff or government, reforms to tax policy, and at one point the Suez crisis caused changes in priorities. ${ }^{62}$ By the late 1960s a strong preference for a treaty had emerged from the two national airlines, both of which were state owned. ${ }^{63}$ In March 1969, the Egyptian embassy in London formally requested a limited DTA, which would exempt each country's national airlines from taxation in the other. ${ }^{64}$ But later that year, when an embassy official spoke with Egyptian tax authority officials, they denied all knowledge of or interest in this proposal, and talks never went ahead. ${ }^{65}$ The only party to seem aggrieved by this was the British Overseas Airways Company (BOAC), which declared itself "bitterly disappointed" that talks had failed, because Egyptian demands for taxation on it were "unreasonable" and "impossible."66

In February 1971, the UK formally requested negotiations on a comprehensive tax treaty, noting that "interest has been expressed by a number of British companies." 67 This followed a letter from the British embassy stating, "I have twice heard suggestions that a general double taxation agreement would be both 
welcome and useful" because some UK firms had faced "harsh tax assessments." 68 However, the request does not seem to have had the support of the Inland Revenue, whose officials observed in an internal memo: "The importance of a comprehensive agreement with Egypt is not clear. We have not called for representations [from industry] as such and neither have any requests been made to us from outside concerns apart from BOAC to take the initiative." ${ }^{69}$ The request appears to have met with a similar fate in Egypt. According to a report from the British embassy in Cairo, "A tax official, on discovering that such an agreement would benefit Britain rather than Egypt because EgyptAir succeeds in never declaring a profit in London for tax purposes, whereas BOAC usually faces a stiff tax bill in Cairo, had decided to sit on the notes and do nothing." 70

The logjam was finally broken four years later, when a joint UK-Egypt economic commission was under way, managed by the Department of Trade, covering a variety of areas of economic cooperation. The CBI's position document on the economic commission recorded "a wide expression of interest in a double taxation treaty with Egypt and there would seem to be little doubt that if a satisfactory agreement can be reached there would be substantial interest among those members we have consulted, in investment in Egypt." ${ }^{\text {"11 }}$ The tax treaty was negotiated in one two-week meeting in May 1976. An Inland Revenue note indicates that the Egyptians "were willing to be led by us most of the time in the drafting" and "for the most part the Egyptians were content" with the British positions. ${ }^{72}$

Egypt's interest in the treaty, however, appears to have been quite weak. The ratification process in Egypt dragged on for years after 1976, during which time it became apparent that the treaty's real immediate impact was in increasing British firms' competitive position. A meeting with a construction firm in 1976 records its frustration that competitor firms from treaty countries benefited from tax-sparing provisions. "They were worried that the absence of a treaty would mean them losing an order and not getting a foothold in Egypt."73 $\mathrm{A}$ letter from BOAC, now British Airways (BA), in 1978 complains that "BA are now the only major airline in Cairo not exempted from Egyptian tax." "I In early 1979, an Inland Revenue document notes that, in the light of delays at the Egyptian end, "we are under some pressure from United Kingdom companies with interests in Egypt to push the convention through Parliament and into force as quickly as possible." 75 The agreement was ratified by Egypt the same year, and by the UK in early 1980 .

\section{Brazil}

The UK devoted far more time and effort to negotiations with Brazil during the 1970s than almost any other lower-income country. It is a negative outlier, an unusual case in which strong pressure from business lobby groups did not translate 
into an agreement, even though there was no organized opposition. When talks were suspended in 1976, the Inland Revenue acknowledged that "it is British investors who will be the sufferers." 76 The transnational expertise perspective outlined in chapter 4 offers an explanation for this outcome. The British position was that it could only conclude an agreement with Brazil, "providing for significant amelioration of aspects of their tax code that run clearly counter to OECD principles; and if they are not interested, so be it." ${ }^{37}$ This nonetheless poses the question why nonexpert interest group pressure was ineffective in the UK, when several other OECD countries had accepted Brazil's non-OECD terms.

Tax treaties with Brazil were in strong demand. Foreign businesses wanted to be part of the country's "economic miracle," and this allowed Brazil to adopt a "take it or leave it" approach to certain unconventional demands. Talks between the UK and Brazil had failed in 1967 but were taken up again beginning in 1972. A particularly difficult issue for the UK was Brazil's insistence that the UK grant extensive tax-sparing concessions. In common with many UK treaties, this would mean crediting the value of a Brazilian tax exemption against the UK company's tax bill as if it had paid full Brazilian tax, but unusually it would also mean doing the same for the reductions in withholding taxes on cross-border payments that Brazil would be able to levy on British investors as a consequence of a treaty. In the reported words of a Brazilian negotiator, "Whilst Brazil does not want the United Kingdom to lose tax, she cannot allow the United Kingdom to collect more tax as a result of the convention.." ${ }^{78}$ Such a concession required an amendment to section 497(3) of the Income and Corporate Taxes Act of 1970 in the UK, the provision that gave effect to tax treaties, and this was passed in 1976.

The second Brazilian demand was more difficult. ${ }^{79}$ Under Brazilian domestic law, firms had to pay a withholding tax on the gross value of any royalty paid to a foreign recipient. Unusually, however, they were not permitted to deduct the value of the royalty payments when calculating their net profits. They also paid tax on the payments through corporate income tax, leading to a high effective tax rate. While the UK's unilateral double tax relief system gave investors a credit for taxes paid abroad, the effective rate in Brazil exceeded this credit, and so the company bore the cost, reducing its competitiveness. Brazil insisted that any tax treaty leave this state of affairs intact, though it was in direct contravention of the OECD model's provisions. Several OECD countries had reached agreements with Brazil that permitted this practice to continue, because other concessions obtained in treaty negotiations, such as lower withholding tax rates, gave their firms a competitive advantage. ${ }^{80}$ This both increased the pressure on the Inland Revenue from British businesses and reduced its leverage in negotiations with Brazil. British companies "are undoubtedly at a competitive disadvantage as compared with companies from other countries," noted a background brief in August 1974. ${ }^{81}$ 
Businesses did not directly lobby the Inland Revenue; rather, they went via other ministries. "Pressure for an agreement with Brazil comes from the DTI, ODA, our Embassy in Brazil and, although perhaps to a lesser extent, from the CBI, in particular RTZ," wrote an Inland Revenue official in November $1973 .{ }^{82}$ In October 1974, a memo from the Department of Industry to the Inland Revenue pressed the case for a treaty, citing "specific evidence of orders being lost by British companies apparently because of their relatively lower post-tax returns forcing them to quote higher prices in compensation." ${ }^{\prime 3}$ With no movement by December, the Department of Trade weighed in, beginning a correspondence between its secretary of state, Peter Shore, and Chancellor of the Exchequer Denis Healey. ${ }^{84}$

As the pressure from business lobbyists on other government departments ratcheted up, tax specialists within British businesses reassured the Revenue that they were broadly in agreement with its view that the Brazilian terms were unacceptable. ${ }^{85}$ In 1974 the Inland Revenue called a special meeting with its regular interlocutors, tax specialists within British multinationals. The latter group agreed with the Revenue that Brazil's terms on royalties would be detrimental in the long term, in view of the precedent that would be set:

The CBI Secretariat (but not the Overseas Tax Panel) are well aware of the powerful trade and political pressures in favour of having an agreement (apparently any agreement) with Brazil which he [Paul Moran of the CBI] thought could lead to an explosion in the autumn. His personal view was that the Revenue and Treasury Ministers could be under pressures from other Ministers which might lead to an agreement, in spite of the unsatisfactory features that had been discussed. Much of the pressure is based on ignorance of the effects of unilateral relief and of the likely terms of a treaty, and it appears that much of it is generated in Brazil and by companies whose only overseas operations are, or are likely to be, in Brazil and which operate on the basis of official handouts. ${ }^{86}$

Minutes of the meeting and a follow-up letter from the CBI record the industry tax experts' frustration at being unable to correct their colleagues' "ignorance" because of the confidential nature of their meetings with the Inland Revenue. ${ }^{87}$ Inland Revenue memos contrast the "non-fiscal voices" within the CBI with those of "the CBI's Tax Committee, as a Committee of tax experts" and observe that "the CBI will no doubt have to consider how to deal with the situation in which it is speaking with two voices." 88

In 1976, British negotiators were able to travel to Brasilia with their new legislative mandate on tax sparing, but with instructions "to refrain from agreeing to the unacceptable features of Brazilian law which they wish to enshrine in the treaty, but to avoid a breakdown in the talks." ${ }^{89}$ While the negotiations did not 
create any further progress, the visit was illuminating for revenue officials. In negotiations, the head Brazilian negotiator (as reported by British negotiators) "frankly admitted that the treatment of royalties was unsound tax practice but made it clear his hands were tied," because of what the minutes describe as "a political decision." ${ }^{\prime 0}$

The Brazilian officials' frustration at political constraints preventing an agreement is revealed more sharply still by a note relating comments made by another negotiator: “Dornelles' No2 (Noqueira) at a dinner given for us last night by the Ministry of Finance told me that they are extremely anxious to get a treaty with the U.K. because their chances of getting one with the U.S.A, Switzerland or the Netherlands are ranked as nil. Switzerland is now second largest investor and will not even discuss a treaty on 'German package' lines. The U.S.A. have an annual meeting with the Brazilians for window dressing purposes only. The Netherlands merely write once a year to enquire whether there has been any change in Brazil's policy."91

After the negotiations, British officials held several meetings with business representatives in Rio de Janeiro. They reached the conclusion that, with one small exception that could probably be resolved unilaterally, there was no genuine problem with double taxation for most firms, despite the idiosyncrasies of the Brazilian tax system. "The impression all three of us got," wrote the chief negotiator, "was that the business community in Brazil were doing very well indeed and that a tax treaty would be a bonus rather than a matter of life or death to them.... They would not be at all impressed with [a treaty] which served only to confirm the undesirable features of Brazilian law." "92 He concluded that the FCO's picture of British businesses' views may have been distorted by the Consul General in Rio de Janeiro, who had become "positively paranoiac about the whole question of a tax treaty with Brazil and has got past the stage, if he was ever there, of being able to consider objectively the arguments against accepting the Brazilians' terms." ${ }^{\prime 93}$

The Brazil files stop at the beginning of the 1980s, but the same debate continues. In 1992, in a separate file, an Inland Revenue official wrote that "Brazil continues to be the big prize: but it is not ripe for an immediate approach and what indications there are suggest that it will be a difficult nut to crack." ${ }^{\prime 4}$ The absence of a treaty with Brazil is still raised by British business lobby groups today, and was mentioned in Parliament in 2014, when the UK-Zambia treaty was ratified: according to the minister responsible, the UK and Brazil still cannot agree on terms. ${ }^{95}$ The Inland Revenue's position is, in effect, that the benefits of maintaining an influential OECD model outweigh the costs to particular UK firms operating in Brazil, and that those costs may in any event be exaggerated.

The debate over the UK-Brazil tax treaty illustrates that the preferences and instrumental power of corporate capital in the UK were not monolithic but varied 
depending on technical knowledge. Had the aim of the UK's tax treaty negotiations been simply to give British firms a competitive edge by lowering their effective tax rate in Brazil, as British firms in Brazil were lobbying for via the British embassy and the DTI, an agreement would have been possible. But it would have come at the cost of implicitly endorsing Brazil's approach to taxing royalty payments. This would have undermined the longer-term project of exporting norms embodied in the focal point of the OECD model, which motivated members of the international tax community both in the Inland Revenue and in businesses.

\section{Nigeria}

Unlike Egypt and Brazil, Nigeria already had a tax treaty with the UK when it first requested negotiations in 1963. This may explain why it took twenty-four years to conclude a new one. The existing treaty was a colonial-era agreement that was, naturally, strongly biased in favor of the (now former) colonial power. While Nigeria's request for a new agreement related primarily to its desire that inward investors from the UK be eligible for tax-sparing credits in the UK, ${ }^{96}$ the Inland Revenue had by 1969 decided not to push forward with renegotiations "since the UK would only stand to lose by a new agreement which was bound to be less favourable than the old." 97 As in the case of Brazil, this cool attitude came against opposition from the High Commission and Foreign Office, which, like the Nigerians, favored a renegotiation to introduce tax-sparing credits. ${ }^{98}$

When negotiations began in earnest a decade later, it was because Nigeria had announced the abrogation of all its colonial-era tax treaties, and the concurrent imposition of new taxes on air and shipping companies. ${ }^{99}$ A telegram from the Inland Revenue to the British embassy in Lagos noted that the government "is very concerned at serious implications of termination of Double Taxation Agreement for British airline and shipping companies," and asked the embassy to request immediate renegotiations "in view of the strength of representation already being made here at senior official level and the probability of escalation to Ministerial level in the near future." 100

The Nigerian government was willing to sign a new treaty, but according to an Inland Revenue official, its proposed draft "would require us to make concessions which are far in advance of the terms which other lower-income countries have accepted in treaties with us." ${ }^{101}$ Progress was made in the first round of talks, including an agreement limited to air and shipping that relieved some of the immediate pressure on negotiators, but at the second round soon after February 1979 it became apparent to British negotiators that "an agreement on the terms offered would have been unattractive in itself and would have served as an unfortunate precedent for future agreements." 102 
The main concern was the rate of tax that could be imposed on fees for technical consultancy and management services, on which Nigeria had declared what one negotiator explained was a "total war." 103 The British economic arguments about the distortionary effect of taxes on management fees carried little weight because Nigeria's position was to use tax to discourage their payment at all. The Revenue discussed the situation in confidence with tax experts within the CBI, who "share our reluctance to reach an agreement until the Nigerians make concessions." 104

The UK view did not change after 1980, but Nigeria moderated its position, and a new treaty was initialed in 1982 . However, the treaty was not actually signed until 1987. The problem seems to have been with the Nigerian treaty approval process, which, unusually, required parliamentary ratification before signature. Although the negotiators on both sides were happy with the treaty, Nigerian officials in other ministries did not take any action to progress it, according to correspondence in the files. ${ }^{105}$ Thus, the signature and ratification were blocked by actors outside the specialist treaty negotiating community.

In both the Nigerian and Brazilian cases, the UK dug in its heels and refused to deviate from the position set out in the OECD model. Why did Nigeria capitulate, while Brazil continued to resist? Drawing conclusions about the negotiating partner's preferences from the UK files is difficult, but we can at least speculate. The Brazilian officials claimed they wanted to accept the UK's terms, and accepted the rationale behind the British position, but they were constrained by political factors preventing them from accommodating the UK. Nigeria's cancellation of a treaty and five-year delay between initialing and signature indicate that-like Egypt—it was more concerned with maximizing tax revenues than with any urgent need to sign a tax treaty. So why did it make the concessions? The files do not contain an answer, other than that the climbdown came after Nigeria had negotiated with a clutch of OECD countries, opening up the possibility that its negotiators had learned what higher-income countries considered "acceptable" tax practices during earlier negotiations. An internal British note describes the original draft proposed by Nigeria as "an opening bid from a country which has had little recent experience in negotiating double tax conventions." 106

\section{Conclusion}

The UK in the 1970s was a quintessential example of a capital-exporting country negotiating a wide tax treaty network. This is usually assumed in policy discourse and in the academic literature to have been a result of competition among lowerincome countries to attract British investment. By examining civil service 
documents, I have demonstrated that this interpretation is incomplete. British firms were at a competitive advantage in any given host market with respect to firms from other countries if those other countries had a tax treaty with the host and the UK did not. As a result, it was usually the UK, not the lower-income country, that made the first move, and indeed the UK was frequently turned down by lower-income countries.

A further disaggregation into different stakeholders allows us to see the two potentially competing ways in which this competition effect worked. For the Inland Revenue negotiators and other tax specialists in the UK (and, the files suggest, their colleagues in other OECD countries), UK firms would benefit if the host country had to follow the "acceptable fiscal standards" set out in the OECD model. In contrast, pressure from businesses was often driven by the pursuit of short-term or parochial gains, especially tax-sparing clauses. Notably, since the UK began to exempt the foreign profits of British multinationals in the mid-2000s, the tax-sparing clauses that motivated both business lobbyists and lower-income countries are now largely redundant.

Importantly, the in-group for decision making within the UK was not defined by occupation but by specialism. Business lobbying was only effective insofar as the Revenue could be convinced that the terms of an agreement were consistent with its overall aim, because the UK treaty-making apparatus gave it a veto, and was further insulated by the technical obscurity of tax treaties that prevented other stakeholders from influencing its activities. Private sector officials who had a tax specialism were brought inside this tent, and their views were influential in decisions made by the Inland Revenue in the Brazil and Nigeria cases, as well as numerous others. Information readily supplied to the business tax experts was at the same time withheld from government officials from other departments on the grounds of confidentiality, and their views dismissed as "ignorant." Even the government ministers supervising tax officials were unable to exert influence because they lacked the technical understanding.

Having focused on the capital-exporting side of the negotiation, the book switches to a focus on capital importers in the next two chapters. These cases support the contention that tax competition is a strategic interaction between capital exporters and capital importers, but they also demonstrate how the latter operates. Just as in the UK, technical knowledge influences preferences concerning tax treaties. In the lower-income country case studies, we see how this can vary over time within the same country, as well as between different stakeholder groups at a given moment in time. 